Meta

Journal des traducteurs

Translators' Journal

\title{
Translation Practices and the Issue of Directionality in China
}

\section{Baorong Wang}

Volume 56, numéro 4, décembre 2011

URI : https://id.erudit.org/iderudit/1011259ar

DOI : https://doi.org/10.7202/1011259ar

Aller au sommaire du numéro

\section{Éditeur(s)}

Les Presses de l’Université de Montréal

ISSN

0026-0452 (imprimé)

1492-1421 (numérique)

Découvrir la revue

Citer cet article

Wang, B. (2011). Translation Practices and the Issue of Directionality in China. Meta, 56(4), 896-914. https://doi.org/10.7202/1011259ar

\section{Résumé de l'article}

Parmi les récents développements en traductologie survenus en Occident, le concept de directionnalité est l'un des plus intéressants. En Chine, le paysage est assez différent, car le thème possède une longue histoire. Le présent article présente les grandes lignes des pratiques de traduction en Chine, la pensée chinoise sur le concept de directionnalité et, enfin, des propositions de recherche. La première partie survole les grands projets de traduction antérieurs ou en cours, ainsi que les positions, passées ou présentes, des chercheurs chinois quant à la directionnalité. Bien que l'accent soit mis sur le tournant du $\mathrm{xx}^{\mathrm{e}}$ siècle, ce survol s'étend du ii ${ }^{\mathrm{e}}$ siècle apr. J-C. jusqu'aux temps présents. Il en ressort que le thème est une pratique très ancienne en Chine, et que la question de la directionnalité n'a commencé à être sérieusement débattue qu'au début des années 1980 pour attirer une attention croissante ces dernières années. La deuxième partie recense brièvement l'état actuel de la recherche et mène à la conclusion que la directionnalité est un domaine peu exploré en traductologie en Chine. En conclusion, appuyées sur des recherches récentes effectuées en Occident, des suggestions de recherches à mener sur ce sujet dans le contexte chinois sont proposées.
Ce document est protégé par la loi sur le droit d'auteur. L’utilisation des services d’Érudit (y compris la reproduction) est assujettie à sa politique d'utilisation que vous pouvez consulter en ligne.

https://apropos.erudit.org/fr/usagers/politique-dutilisation/ 


\title{
Translation Practices and the Issue of Directionality in China
}

\author{
BAORONG WANG \\ Zhejiang University of Finance and Economics, Hangzhou, China \\ abrwang.cls2011@gmail.com
}

\begin{abstract}
RÉSUMÉ
Parmi les récents développements en traductologie survenus en Occident, le concept de directionnalité est l'un des plus intéressants. En Chine, le paysage est assez différent, car le thème possède une longue histoire. Le présent article présente les grandes lignes des pratiques de traduction en Chine, la pensée chinoise sur le concept de directionnalité et, enfin, des propositions de recherche. La première partie survole les grands projets de traduction antérieurs ou en cours, ainsi que les positions, passées ou présentes, des chercheurs chinois quant à la directionnalité. Bien que l'accent soit mis sur le tournant du $\mathrm{xx}^{\mathrm{e}}$ siècle, ce survol s'étend du $\|^{\mathrm{e}}$ siècle apr. J.-C. jusqu'aux temps présents. II en ressort que le thème est une pratique très ancienne en Chine, et que la question de la directionnalité n'a commencé à être sérieusement débattue qu'au début des années 1980 pour attirer une attention croissante ces dernières années. La deuxième partie recense brièvement l'état actuel de la recherche et mène à la conclusion que la directionnalité est un domaine peu exploré en traductologie en Chine. En conclusion, appuyées sur des recherches récentes effectuées en Occident, des suggestions de recherches à mener sur ce sujet dans le contexte chinois sont proposées.
\end{abstract}

\section{ABSTRACT}

Directionality is one of the most interesting recent developments in translation studies in the West. The scene, however, is rather different in China with a long history of inverse translation. This article aims to outline translation practices in China and Chinese thinking on directionality while providing a few pointers for further research. Part one surveys major translation projects that were carried out or are being carried out and how Chinese translation scholars thought/think about directionality. The survey covers nineteen centuries from the $2^{\text {nd }}$ century A.D. through the present time, albeit most of the data are devoted to the periods from the turn of the $20^{\text {th }}$ century. It is found that although inverse translation is an age-old practice in China, the issue of directionality began to be seriously considered and debated only in the early 1980s, and that there has been increased attention to the topic in recent years. Part two briefly reviews the current status of research and concludes that directionality is an under-researched area in Chinese translation studies. The article ends with some suggestions for further research on the subject in the Chinese context, drawing on the latest research conducted in the West.

\section{MOTS-CLÉS/KEYWORDS}

directionnalité, thème, traduction centrifuge, Chine, domaine sous-investigué directionality, inverse translation, outward translation, China, under-researched area

\section{Introduction}

Directionality or direction of translation usually refers to whether translators work from a foreign language into their mother tongue or the other way round (Beeby 1998: 63-64). The former procedure is generally referred to as "direct translation" 


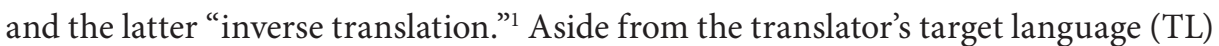
capacity, directionality also involves the complex network of economic, political, cultural, professional, and personal circumstances. Hence, it is deemed an engaging but also very complex and controversial issue (Godijns and Hinderdael 2005: 3, 8). While directionality is one of the oldest issues discussed in Western translation and interpreting community (Gile 2005: 9), research into the subject did not emerge until the end of the last century. Despite this, today the scope of research is quite broad, and fresh insights and results are flooding in (Beeby 2009: 84).

China has a long history of inverse translation, and today translation out of Chinese is being practiced even more commonly than ever. ${ }^{2}$ However, directionality is a hitherto largely ignored subject in the country. In fact, even the notion "directionality" itself and such terms as "direct," "inverse," "service" translation are not yet in currency. ${ }^{3}$ Beeby (1998: 64; 2009: 84) notes mistakenly that directionality is described in Chinese in terms of a translation being "direct" or "inverse." As it is, the notion is often encapsulated by yiru (译入, meaning literally "inward” translation) and yichu (译出, “outward” translation). Broadly, yiru (译入) and yichu (译出) refer respectively to translation into/out of the mother tongue and hence are roughly equivalent to direct translation and inverse translation. However, yiru (译入) and yichu (译出) used in contemporary Chinese discourse on translation often refer to translation into/out of Chinese by native translators (see Chan 2003; Pan 2004; Hu 2006). The latter use is closely related to the conception of China being the center of the universe. This will be discussed in more detail in the second part.

Another term requiring clarification here is "team translation." It is defined rather narrowly as the working arrangement where one member of the team is an inverse translator and the other a direct one (Beeby 1998: 67). But there are often other modes of collaboration. Teamwork poses problems for translation scholars since in many cases it is difficult to determine the direction of translation. As will be demonstrated below, the Chinese tradition features what can be termed "Chinese-style team translation," where foreign missionaries not well-versed in the TL translated into Chinese with the help of their Chinese collaborators who were generally innocent of the source language (SL). Given the fact that there was no such thing as the Chinese partners translating into Chinese, teamwork of this nature is treated as inverse translation in this article. For the purpose of this article, these Chinese designations for directionality and China's unique translation practices should be included to complement the Western notion of "directionality."

This article aims to outline China's history of directionality practices in translation and current research on directionality while providing a few pointers for further research. Part one surveys major translation projects that were undertaken or are being undertaken in different periods of time and how translation scholars thought/ think about directionality. Part two briefly reviews the current state of research on directionality and offers some suggestions for further research in the Chinese context, drawing on the latest research conducted in the West.

\section{Translation Practices and the Issue of Directionality in Chinese Translation History}

This historical overview covers nineteen centuries from the $2^{\text {nd }}$ century A.D. through the present time. Most of the data are devoted to the periods starting from the turn 
of the $20^{\text {th }}$ century while the preceding ones are only given a quick run-through, thanks to some earlier work (e.g., Hung 1999). Three kinds of data are included: major translation projects and directionality practices; the political, economic, and sociocultural reasons involved; and Chinese thinking about the issue of directionality.

\section{1. $2^{\text {nd }}-19^{\text {th }}$ Century: Prevalence of Chinese-style Team Translation and Disregard for Directionality}

China's recorded history of translation can be traced back to Zhou Dynasty (ca. $11^{\text {th }}$ c.-256 BC). The first wave of major translation activities came in the wake of the spread of Buddhism (Hung and Pollard 1998: 365-366). Largely due to its own cultural deficiency and the concomitant need for the importation of foreign culture, China saw three peak periods during which foreign knowledge and learning were actively introduced through translation: the Buddhist scripture translation movement $\left(2^{\text {nd }}-9^{\text {th }} c.\right)$, the Jesuit translation activities in the late-Ming and early-Qing period $\left(16^{\text {th }}-17^{\text {th }}\right.$ c.), and the introduction of "Western learning" in the latter half of the $19^{\text {th }}$ century. The duration of these periods varied greatly, as did the socio-cultural factors that gave rise to the translation projects and the impact they produced on Chinese culture.

A historical survey leads Eva Hung to conclude that "all three periods were characterized by one prominent feature - the leading role played by non-Chinese translators" (Hung 1999: 223-226). ${ }^{4}$ The fact that these historical periods, particularly in the early stages of each, all featured the activities of foreign missionaries in China can partly explain why foreign translators played such a crucial role. ${ }^{5}$ However, the fundamental reason is that mainstream Chinese intellectuals, who tended to pride themselves upon the superiority of their own culture, never bothered to learn about foreign languages and cultures. Consequently, the dynastic governments were perpetually distressed by the paucity of competent native translators. ${ }^{6}$ Small wonder "major translation activities depended heavily on foreign translators for [their] language as well as cultural expertise" (Hung 1999: 224).

It is a pity that although Hung removes the "veil" which has long obscured the contribution of foreign translators, she overlooks the tricky issue of directions in translation. Owing to the general shortage of native translators, Chinese-style team translation was the norm in these periods. While the specific mode of collaboration and translation method varied from period to period, directionality practices remained static over the centuries: the foreign party interpreted or translated into Chinese while the Chinese party recorded and polished the Chinese version. With the exception of a few Chinese monk-translators (notably Xuan Zang) who presided over translation forums, Buddhist scriptures were invariably translated with the foreign monk serving as the Chief Interpreter (yizhu 译主) and the Chinese monk as the Recorder (bishou 笔授). The seminal scientific works rendered into Chinese in the $16^{\text {th }}-17^{\text {th }}$ century are also co-translations: the Jesuits translated the original into Chinese, and the draft version was polished by Chinese scholar-officials, their collaborators. ${ }^{7}$ The practice was repeated in the $19^{\text {th }}$ century: the foreign experts translated and explained verbally to Chinese collaborators who took their words down and made a draft version, which was then polished by often monolingual Chinese scholars (Hung and Pollard 1998: 369-370). Since there was virtually no such thing 
as the Chinese partners translating into Chinese, translations produced in this manner are, arguably, inverse ones. Pan (2004: 42) argues rightly that contemporary Chinese scholars tend to accept sci-tech translations into Chinese made in the $16^{\text {th }}$ $17^{\text {th }}$ century as "inward" translations by the Chinese, "but they are actually 'outward' translations by the Jesuits."

Chinese-style team translation that prevailed between the $2^{\text {nd }}$ and $19^{\text {th }}$ centuries has had profound effects on Chinese translation tradition. One of these is on Chinese thinking about directionality before the turn of the $20^{\text {th }}$ century. Since the foreign missionaries often assumed the role of chief translators, translating out of their native languages, while their Chinese collaborators only served as recorders or polishers having almost no say on what and how to translate, there was not a fertile ground for advocacy of direct translation (i.e., the Chinese should translate singlehanded into Chinese). Naturally, the issue of directionality passed unnoticed.

\subsection{Turn of the 20th Century-1949: "Inward" Literary Translations and Establishment of the Mother Tongue Principle}

Lefevere (1998: 13) suggests that "cultures that see themselves as central in the world they inhabit are not likely to deal much with Others, unless they are forced to do so." This was exactly the case with China before the turn of the $20^{\text {th }}$ century. Major translation projects were invariably initiated and carried out by foreign missionaries, whose endeavors were often sponsored by the Chinese government either for better rule of the people or cultural regeneration. At the end of the $19^{\text {th }}$ century, however, China was on the verge of ruin under foreign military threat; hence, translation became an essential means for national survival. This greatly changed translation practices and attitudes toward directionality.

To save the Chinese nation from imminent destruction, the famous political reformist Liang Qichao (1873-1929) published two influential articles in 1898 and 1902. In the former Liang introduced the term "political fiction," stressing the crucial role fiction played in affecting and improving politics in foreign countries. In the latter he called for a "revolution in fiction," arguing that "in order to transform the people of a country, the only way is to transform its fiction" (Liang 1902/1989: 33). Thus began the New Fiction Movement which marked the first time in Chinese history when literary works became the focus of translation activities. The most prolific translator of Western literature is Lin Shu (1852-1924). Despite his ignorance of any foreign language, Lin collaborated with his Chinese interpreters to render about 180 titles, mostly novels, from English or French into classical Chinese.

After the 1919 May Fourth Movement, which helped accelerate the importation of Western writings, translation came to the fore and China's traditional dependence on foreign translators ended. Now that translation was prized as a vital tool for national regeneration, it could no longer be left in the hands of the nationals of aggressive powers. Meanwhile, there emerged a new generation of intellectuals well versed in foreign languages by virtue of having studied abroad or attended missionary schools at home. Nearly all of them engaged in translation, some on a massive scale, although it was often the lonely pursuit of individual translators. In consequence, the need for foreign translators had almost vanished by the 1920s and the age-old practice of Chinese-style team translation was abandoned for good. Most of the translations 
produced in the 1920s-1940s were literary, with amazingly large productions in certain periods. ${ }^{9}$

Since native translators of the age almost always worked into Chinese, directly or indirectly (intermediate translation was common), it gradually became axiomatic that translators should work into their native language, leading to the establishment of the "mother tongue principle" in the Chinese tradition (see Thelen 2005: 242). Yan Fu (1854-1921) might be the first Chinese scholar to suggest that one should translate only into one's mother tongue. In the preface to his translation of Thomas Huxley's Evolution and Ethics (Tianyan Lun), he laid down three criteria for translating, i.e., “faithfulness" (xin 信), “communicability" (da 达), and “elegance” (ya 雅) (Yan 1898/1984: 136). Yan's advocacy of elegance, which derived from his using classical Chinese as the medium of translation, reveals his assumption about the direction of translation. Yan's desiderata have left the deepest mark on translation studies in China and are still held up by many Chinese translation scholars as "golden rules" (Hung and Pollard 1998: 376).

The mother tongue principle as Yan Fu assumed was generally accepted and reinforced by later generations of Chinese intellectuals. It recurs frequently in modern Chinese writings on translation. For instance, Guo Moruo (1892-1978), an eminent Chinese scholar-cum-translator, maintains that "[o]ne of the prerequisites for producing 'ideal' translations is that the translator should master his native language" (Guo 1923/1984: 331). Lin Yutang (1895-1976), who translated much more from Chinese into English than the other way round, presumes like the others that Chinese translators should work only into Chinese:

What the art of translation depends on is, [...] Secondly, the translator has a fairly good command of his own language, capable of writing clear and fluent Chinese. The problem of smoothness in translation is basically one of rendering Western thoughts into one's own language. (Lin 1932/1984: 417, 427)

The above quotations show that in the 1930s the mother tongue principle was already well-established in the Chinese tradition. However, it would be presumptuous to assume that these authors uncritically accepted Yan's assumption about directionality. Since translation into the mother tongue (i.e., Chinese) was the norm in those days, it was simply accepted as the fact of translation. Nevertheless, a small number of pioneers of Chinese-English translation emerged in this period. Su Manshu (18841918) and Gu Hongming (1857-1928) are among the best known inverse translators around the turn of the $20^{\text {th }}$ century. Lin Yutang is the leading figure in producing English translations of classic Chinese texts in the 1930s. But their venture, often arising from their own enthusiasm for a particular writer's works, was inevitably "unsystematic" (Ma and Ren 1997: 699-704). And the output was not large enough to challenge the then predominant practice of "inward" translation.

\subsection{0s-1960s: First Wave of "Outward" Translations and Continued Assumption about Directionality}

Even before the PRC was founded in 1949, the Communist leaders had had a strong sense of being economically, politically and culturally isolated. Against this backdrop, the International News Bureau (the predecessor of the Foreign Languages Press - 
FLP) was set up in Beijing in the same year, whose mission was "to break down the blockade of New China imposed by the imperialist powers and to introduce the People's Republic of China to the outside world" (Yang 1999: I). Hence, from the very beginning the bureau was designed to serve as a vehicle for political propaganda. McMorran (2000: 281) notes aptly that the PRC wanted to "make its culture known abroad, even if at times this effort has taken the form of fairly crude political propaganda." Nevertheless, this marked China's first attempt to sponsor large-scale "outward” translations, and it was very likely that the charged term yichu (译出) was coined in this period.

In 1952 the FLP launched a grand scheme for translating Chinese writings into foreign languages, particularly major Western languages. In addition to the Party and government documents as well as the writings of such political leaders as Mao Zedong, Liu Shaoqi, Zhou Enlai, works of Chinese literature (classic, modern, and contemporary), philosophy, history, etc. were also included. ${ }^{10}$ The ambitious project was disrupted by the Cultural Revolution which raged from 1966 to 1976.

At the FLP, teamwork was the standard practice: native translators worked alongside "foreign experts" whose contribution was generally limited to revising and polishing the drafts (Dai and Chen 1999: 62). ${ }^{11}$ One reason for this working arrangement was that the Chinese translators were "remarkably skilled," capable of making "correctly done" translations (Jenner 1990: 187; Lee 1985: 566). But the translator's political allegiance should be the main consideration. Since it was political propaganda (even if the original text might be literary), how could it be entrusted to those "politically unreliable" foreigners?

The doyens of translation into English at the FLP were Yang Xianyi and Gladys Yang. The Chinese-British couple has been responsible for a vast number of translations, including the classical Chinese novel Dream of Red Mansions, the modern fictional classic Selected Stories of Lu Hsun, etc. Generally admired for their precise and fluid translations, the Yangs "contributed directly and indirectly to the development of Chinese studies in the West" (Davin 2009).

Designating such translation endeavors as "cultural self-translation," Hung (2002: 330-331) links them to the PRC government's political agenda: "If self-translation is all about cultural image projection, it is natural to try and project one's ideological beliefs into the enemy camp. Equally natural is the attempt to effect that projection in the language of power and prestige." Pokorn (2005: 35-37) notes that inverse translation is common in large linguistic communities like China because global distribution of power has reduced them to a "peripheral position." This can explain why China has been sponsoring "outward" translation projects since the 1950s.

Meanwhile, "inward" translation continued to be carried out. Some of the projects were sponsored by the government (e.g., the works by Marx, Lenin, etc.). Yet even for individual endeavors, the selection of texts for translation was strictly controlled. For ideological and political reasons, the Soviet Union was the chief source of works for translation to begin with, but later on the literatures of the Third World came to enjoy unprecedented attention. This resulted from China's political resolve to be allied with these countries in an effort to resist Western imperialism.

Since "outward" translation was restricted to the state-run institutions and the native translators generally avoided talking about their own work, often a "political 
task" and a potentially sensitive issue for them, inverse translation was not widespread enough to challenge the then prevailing practice of direct translation. Therefore, discourse on the mother tongue principle still rang loudly in this period. The following are some representative remarks:

The translator must have a deep understanding of the original text and after digesting it fully in his stomach, so to speak, convey it to his countrymen in his native language. (Feng 1959/1984: 646)

In theory, mastery of one's native language and representation of the original style are two inseparable aspects of literary translation. The very nature of literary translation requires that we convey the original style in our native language (Bian, Ye et al. 1959/1984: 657-658).

In fact, this implicit assumption about directionality still echoed in the 1970s. Fan, for example, argues strongly that " $[w]$ e write or translate not for the 'literati,' but for the general population. Hence, we must write and translate in modern Chinese as is comprehensible to the people, not in the language of antiquity" (Fan 1978/1984: 780 ). As can be clearly seen, the position held by these authors is generally impressionistic and intuitive, not supported by serious theorizing whatsoever.

\subsection{0s-present: New Surge of "Outward" Translations and Growing Attention to Directionality}

Since English became an international language in the 1950s, translators in many non-English speaking countries have turned to inverse translation with greater frequency (Shuttleworth and Cowie 1997: 90). Such has been the case with China since the late 1970s. While the 1980s saw an explosion in the translation of foreign works, China's "opening-up" program launched in 1978 created a huge market for non-literary translation, mostly into English. The texts to be translated include business contracts and correspondence, promotional and publicity material, sales literature, instruction manuals, etc. For some practical factors, e.g., much lower translation fees in China, the scarcity of native-English translators having enough Chinese, the texttype involved where the need for perfect style is not so pressing, etc., most of the translations were made by native translators. Some of them were in-house professionals, but most of them worked part-time or as freelancers. As the practitioners generally had but a shaky command of English, their translations, often not revised by native speakers of English, were notoriously rife with errors. This led people to start thinking about the suitability of native translators for handling inverse translation. Hence, serious attention to the issue of directionality emerged.

Cheng Zhenqiu, one of the first Chinese translators to dwell on the issue, begins by establishing the different requirements of the translator's competence created by the direction of translation. He holds that comprehension generally requires a passive knowledge of words while expression requires active use of words. Quoting Quirk's assertion that "our 'passive' knowledge of words is always so much greater than our 'active' use of words," Cheng (1980: 1-2) concludes that "translators throughout the world generally work into their native language." In a more recent paper, Cheng (1992: 38) argues further that as a rule translators should work only into their mother tongue, because "with only rare exceptions, people often have a better command of 
their native language than of a foreign one." However, Cheng stresses that although translation out of Chinese is more difficult for native translators than the opposite procedure, "there is now a huge amount of translation into English for us to cope with in order to introduce China to the wider world and to engage in international exchange."

Some Chinese scholars, both stimulated by China's economic success and obsessed with "the traditional sense of being heirs to a superior cultural heritage" (Hung 2000: 33), have felt an urgent need to "send out" the essence of Chinese culture to the outside world. Ji Xianlin, the late Peking University professor, even coins the term “send-out-ism” (songqu zhuyi 送去主义), arguing that China has taken much from the West in the greater part of the $20^{\text {th }}$ century, and now it is China's turn to give something back (quoted in Wang 2000: 300). This leads Professor Wang Ning of Tsinghua University to suggest that Chinese literature and culture should be exported on a massive scale "to readdress the imbalance in East-West cultural interchange" (Wang 2000: 303). Meanwhile, despite China's economic clout, "Chinese leaders have long worried about China's lack of soft-power influence of the sort that the U.S. and Europe achieve through their prominent roles in media and arts" (Ramzy 2009). This accounts for the launching of the government-sponsored Library of Chinese Classics (LCC) project in 1995, "the largest ever of the kind since 1949" (Yu 2007: 99). To date more than 100 volumes of Chinese classics in Chinese-English bilingual editions have been published, covering literature, history, philosophy, politics, economy, military science, and science and technology. While most of them are reprints of established translations, some are made by Chinese translators for the first time, "polished by foreign experts." 12 The native translators include both accomplished ones (Xu Yuanchong, Lin Wusun, Wang Rongpei) and younger ones (Zhai Jiangyue, Liang Xiaopeng, Zong Fuchang, etc.). ${ }^{13}$

Faced with this new surge of "outward" translations, some advocates of "sendout-ism" have called upon native translators to render Chinese classics into foreign languages. $\mathrm{Hu}$ (2003), for example, opines that while those "liberal-minded Westerners" should be encouraged to translate Chinese writings, "we must do the bulk of the job ourselves, because we can never count on the Westerners to expend huge amounts of money for the purpose." Hu argues that Chinese translators can do an equally good job in translating Chinese classics: "who is stronger, who is weaker, it all depends on the translator's individual abilities, not on his/her mother tongue." Hu's argument, however, is based only on speculative discussion and anecdotal evidence.

Professor Pan Wenguo of East China Normal University challenges the validity of the mother tongue principle prevailing in the West. In his polemical article, Pan (2004) raises three points to refute A. C. Graham's assertion about the direction of translation. ${ }^{14}$ First, individual cases of poor translation do not mean that the Chinese are not suited for handling yichu (译出; i.e., translation out of Chinese). In fact, native-English translators handling Chinese texts may also produce unsatisfactory translations. Second, native-English translators might enjoy a "linguistic advantage" over non-natives, but they are often baffled when it comes to the comprehension of the original. As it is, one who understands the original poorly cannot produce a successful translation. Third, due to the special difficulties of Chinese classics and Chinese characters, there are few exceptions to the rule that native-English translators, however well-versed they are in Chinese, frequently make errors. Hence, "the 
collaboration of Chinese scholars should be sought if a native-English translator wishes to produce a quality translation." Pan concludes that English translation of Chinese classics is not "the privilege of foreign translators" and Chinese translators, so long as they are steeped in both Chinese and English, "should undertake the task with full justification and confidence."

There has long been a general discontent among Chinese scholars with many translations made by foreign translators, and it often serves to justify the Chinese practicing inverse translation. Wu (1986: 6-7, 13), for instance, criticizes certain foreign translators who according to him "did not do justice to the original authors, and distorted the image of classical Chinese poetry." Hence, Wu suggests that "those of us who master a foreign language should translate classical Chinese poetry by ourselves." In similar vein, Cui (2007: 43-46) warns that earlier Western sinologists and missionaries "created a distorted image of the Oriental nations by writing about China and rendering Chinese classics into European languages." Cui argues that as such "improper" translations have subjected the Chinese nation to Euro-American cultural hegemony, "we should translate Chinese classics on our own," trying to preserve Chinese culture and the artistic features of the Chinese original in the translation. As a matter of fact, this strong sense of discontent contributed to the launching of the LCC project. Yang Muzhi, chief editor of the series, observes that since in general Western translators lack knowledge of Chinese language and culture, their translations are often unsatisfactory: "not only are Chinese classical writings widely misunderstood in the rest of the world, in some cases their content has actually been distorted" (Yang 1999). ${ }^{15}$

This enthusiastic call for "outward" translation, however, has met with criticism. $\mathrm{Hu}$ (2005), for example, maintains that since as a rule one should translate only into one's mother tongue, English translation of Chinese writings should be left to nativeEnglish translators. In another article, $\mathrm{Hu}$ (2006) argues that in theory the Chinese can try their hand at "outward" translation, but there is no denying the fact that few Chinese translators can produce fluent and acceptable translations. Hu thus suggests that teamwork by a native-English translator and a Chinese scholar should be the best way of handling "outward" translation. She also emphasizes that serious attention must be paid to the reception of a translation and that the translator should select such a translation strategy as can ensure that the translation is well received in the TL culture. At this point, Hu criticizes Pan's (2004: 43) proposition that in an effort to resist Eurocentrism and "effect cultural intervention" through "outward" translation, Sino-English used by Chinese translators "not only can be tolerated, but should also be encouraged." Hu contends that Sino-English is used by incompetent Chinese users of English; it is therefore ridiculous to argue that such English should be encouraged to "resist pure English."

Xie 2008 (quoted in Wang 2008: 12) points out that despite the PRC government's sustained efforts to patronize "outward" translation, "the outcome is not as good as we expected." He attributes this to the fact that Chinese translators tend to "work behind closed doors," i.e., they are merely intent on producing "good" translations, caring little about how the product is received by the target readers. In his monograph, Xie (2007: 210) argues that foreign translators might not match their Chinese counterparts in understanding the Chinese original, but they often have a better command of the TL which is their mother tongue, and their translating style is often 
more readily acceptable to their readers. Therefore, their translations command a comparative advantage in winning over the general Western reader. Xie (quoted in Wang 2008: 12) cites the two English translations of Hongloumeng: A Dream of Red Mansions by Yang Xianyi and Gladys Yang, and The Story of the Stone by David Hawkes. Comparing the two versions in terms of the frequency of loan and citation, circulation and the number of reprints, Xie finds that Hawkes's version is far more popular in the United States than the Yangs's. Nevertheless, Xie believes that Chinese translators can pull off "outward" translation if they can write in an English that is readily acceptable to English readers. He also recommends team translation to ensure that a translation is well received.

\section{Studying Directionality in China}

\subsection{Current Status of Research}

The above brief survey shows that since the early 1980s there has been growing attention to directionality in China. But the observations and writings generally lack theoretical depth and analytical rigor, revealing the fact that Chinese translation scholars are "prone to vague, impressionistic assertions concerning translations" (Chan 2004: 3). This weakness also exists in current research on interpreting in China, which lacks empirical studies and corpus-based studies and features speculative discussion and personal narratives about practice or training (Wang and $\mathrm{Mu}$ 2009: 279; Setton 2009: 113). One should not be taken aback when Lao (1996: 41) criticizes that " $[\mathrm{o}] \mathrm{n}$ the one hand, there is a large amount of translation being carried out without theoretical guidance; on the other hand, there is an endless line of hollow theories being produced in the field." Zhu (2004: 337) notes that such theories are deemed "hollow" because they "tended to base themselves on impressionistic, anecdotal, or judgmental accounts.” Lao's somewhat harsh criticism is particularly valid for the case of inverse translation, which has long been practiced in China "without theoretical guidance."

Many Chinese translation scholars have felt an urge to formulate some translation theory featuring "Chinese characteristics." If Chinese-style team translation and "outward" translation can be accepted as one such characteristic, then the issue of directionality, which one would expect to have been well-researched, is obviously under-explored. This is to some extent reflected in the fact that the notion of "directionality" and related terms have not yet gained currency in China. Instead, yiru (译 入, “inward” translation) and yichu (译出, “outward" translation) are commonly used to refer to directionality. However, these two terms are not so much related to the translator's native tongue as to the conception of China being the center of the world. China is one of the world's oldest continuous civilizations; hence the Chinese used to believe that China was the center of civilization. This is shown in the name of their country: 中国 (zhōngguó; China) means "Middle Kingdom" or "central country." From the 1850s on, Chinese culture began to be relegated to minority status in the general scheme of things, but the traditional sense of cultural superiority has remained. Today this feeling coupled with China's rising international status often gives rise to cultural anxiety: an itch for greater worldwide recognition of its culture. Hence, the Chinese instinctively see the term yiru (译入) as denoting the translational 
act by which foreign culture moves to the center (i.e., China) and often treat it with mixed feelings: they fear that native culture will be contaminated although they are confident it will prevail. The opposite yichu (译出) is thought of as the translational act by which Chinese culture moves from the center to the outside world. There is need for yichu (译出) because it is realized that the center has long since been marginalized. But the Chinese also tend to justify yichu (译出) by claiming that Chinese culture (esp. Chinese classics) is worth being translated. Here again, mixed feelings of superiority and anxiety are in full play.

As shown in the first part, the current use of yiru (译入) and yichu (译出) often turns directionality into a highly charged issue in China and therefore might not contribute to serious research in the field. While such value-free terms as "directionality," "bidirectionality" and " $\mathrm{A} \rightarrow \mathrm{B}$ translation" are being increasingly used in the West, Chinese translation scholars still lack proper terminology for directions in translation.

Zhu (2004: 332) notes that translation involving Chinese, both as the SL and TL, has been actively studied in China, "but most of such studies are published in Chinese." While this is largely a correct observation, directionality is definitely a notable exception. A topic search of the China Academic Journals Full-text Database (1915-2009) and the China Master/Doctor Theses Full-text Database (1999-2009) shows that so far no journal articles or degree theses, whether in Chinese or in English, have been devoted to the topic. ${ }^{16}$ Sure enough, Chinese contribution to the subject is so meager that it has not been recognized internationally. This is indicated by the updated entry "directionality" where "Directionality in translation studies" is superseded by "Directionality in contemporary Western translation studies" (Beeby 2009: 84). One might dismiss this as Eurocentrism, but the true picture is laid bare.

There are, however, some serious investigations by a small number of scholars in Hong Kong and Taiwan. Eva Hung, a Hong Kong scholar, has published three English articles on the issue $(1991 ; 2000 ; 2002)$, throwing fresh light on what she terms "SL culture-initiated translation" or "cultural self-translation." These articles have helped attract the attention of Western translation scholars to the practice of inverse translation in the Chinese tradition. Chang Chia-chien, a Taiwan scholar, has co-authored an important article with an American professor. Their empirical study deals with directionality in simultaneous interpreting by exploring professional Chinese-English interpreters' experience, focusing on the impact of language direction on their choice of strategies (Chang and Schallert 2007). These pioneering studies serve as good examples for mainland Chinese translation scholars.

\subsection{Suggestions for Further Research}

Directionality is not yet a well-researched subject in the West. Theorizing about and empirical research into it did not emerge until at the end of the last century. As English-speaking scholars generally shun the idea of inverse translation, most researchers hail from countries where inverse translation is a common practice (Beeby 2009: 84-87). The immaturity of the subject is partly reflected in the lack of consensus about the terminology denoting directionality. Moreover, Godijns and Hinderdael (2005: 3) note that "very subjective and emotionally charged" arguments for or against retour interpreting are common. Gile (2009: 56) observes that it is still 
not possible to evaluate the "relative merits" of interpreting into the A language and retour interpreting, because "they have not been investigated empirically to a sufficient extent to allow any clear conclusions to be drawn."

Despite this, Chinese translation scholars can draw tremendously on the academic efforts their Western counterparts have made so far. In the past decade, directionality has been studied so actively in the West that it is hailed as "one of the most interesting recent developments in translation studies" (Martin 2005: 89). This is evidenced by two recent international conferences: one was held at the University of Ljubljana, Slovenia, in May 1997, and the other at the University of Granada, Spain, in November 2002. The proceedings of the two conferences have come out (Grosman, Kadric et al. 2000; Kelly, Martin et al. 2003). The year 2005 saw the publication of two influential books: Pokorn's Challenging the Traditional Axioms and Directionality in Interpreting edited by Godijns and Hinderdael. They indicate that " $\mathrm{t}]$ he debate on directionality has been resumed in recent years with increased vigor across both translation and interpreting studies" (Hild 2006: 223).

Since inverse translation carried out in China links closely to its unique sociopolitical circumstances, Western translation theories and empirical findings do not often lend themselves well to the Chinese context. However, the various approaches adopted and the broad issues covered should be most enlightening to Chinese translation scholars, let alone the need to adopt the notion of "directionality" and related terms. The following are some suggestions for further research on directionality in China, drawing on the latest research in the West.

\subsubsection{History of Inverse Translation}

Although inverse translation is an age-old practice in China, a history of inverse translation has not yet been written. Such a history is of consequence because "[w]e do translation history in order to express, address and try to solve problems affecting our own situation" (Pym 1998: x). That is, knowledge of China's history of inverse translation provides a good point of departure from which we study directionality. Research questions to be answered, among others, include: Why has inverse translation been commonly practiced in China? Why did inverse translations occur at a particular time? Why is inverse translation as an established practice in China underexplored? For instance, why did the PRC government make it a policy in the 1950s that translation of Chinese writings must be left to native translators? Hung (2000; 2002) offers some insightful explanation, but the situation was far more complex. Beeby (2009: 86) notes that in certain countries directionality is determined by norms designed to ensure the translator's political allegiance. Martin (2005: 84-85) suggests that in the case of the Soviet model which prefers inverse translation, there are "ideological considerations conditioning language direction": before 1989 the interpretation of Soviet thought was rarely entrusted to non-Soviet interpreters. Given the "brotherly" Sino-Soviet relations in the 1950s, China could have adopted the Sovietstyle ideological control over translation.

\subsubsection{Empirical Research}

Empirical research is seriously lacking in Chinese translation studies. Liao (2009) observes that Chinese researchers are still borrowing and familiarizing themselves with such research methodology from the West. Survey studies using questionnaires, 
interviews, think-aloud protocols, etc. can, for example, look into everyday practice of professional translators and interpreters and their attitudes towards directionality (see Martin 2005; Pavlović 2007). We are in bad need of textual data concerning the percentage of translators/interpreters who frequently or occasionally translate out of their native language, the translators' (and also their clients') attitudes towards inverse translation, how they assess the impact of directionality on translation quality, etc.

\subsubsection{Corpus Studies}

In both China and the West, debates over inverse translation often center on the assumed differences in quality between direct translations and inverse ones. But are there any marked differences between translations arising from two directions of translation? Or is inverse translation necessarily inferior to direct translation? Such controversies can only be settled by eliciting sufficient evidence from corpus-based studies. Pokorn (2005), for instance, tries to challenge the assumption that only translation into one's mother tongue can provide good quality. She creates a small corpus for textual analysis: three literary texts by a Slovene writer and their English translations. This is corroborated by a questionnaire survey to elicit the target readers' response to the translations. The findings show that translation quality does not depend on the translator's mother tongue or the direction of translation, but on the translator's individual abilities, translation strategy, and knowledge of the two cultures (Pokorn 2005: xii). Interesting as the study is, its findings are questionable. Chan (2007: 287-288) pinpoints two limitations of Pokorn's study. For one thing, the corpus is restricted to literary texts, while "non-literary data can produce more accurate results than literary data for studies of this kind." For another, Slovene is not as distant from English as Chinese is; "using the language pair of Chinese-English may produce very different results in another study." Chan's claim, of course, needs to be substantiated by further research. But another problem of Pokorn's study is the smallness and the resultant low representativeness of the textual data. A study based on such a small corpus cannot provide reliable results. ${ }^{17}$

\subsubsection{Directionality and Translator/Interpreter Training}

No trainer can evade the issue of directionality. This is probably why most articles in Grosman, Kadric et al. (2000), Kelly, Martin et al. (2003) and Godijns and Hinderdael (2005) are contributed by Western translator/interpreter trainers. With a view to enhancing training effectiveness, they are particularly interested in investigating the effects of directionality on trainee translator/interpreter competence and performance, with specific language pairs. Although retour interpreting is generally not offered as a separate course in Spanish interpreter training institutions (Fernández 2005), Spanish translator/interpreter trainers are most actively engaged in research on directionality. In China, however, there are virtually no empirical studies on the relationship between directionality and translation competence although translator/ interpreter training in Chinese universities has been bidirectional since the late 1970s (Xu 2005: 234-240). It is therefore high time that Chinese translator/interpreter trainers studied the effects of directionality on trainee translator/interpreter performance, using the language pair of Chinese-foreign languages. Other related important research questions include: trainee translator/interpreters' strengths and limitations 
in doing $\mathrm{A} \rightarrow \mathrm{B}$ translation, the genres or text-types suitable for inverse translation, etc. (see Beeby 1996).

\subsubsection{Domestic Consumption of Inverse Translations}

There is a unique phenomenon in China: many made-in-China inverse translations aimed at international readers are also used for domestic consumption. This is confirmed by the publisher's note to the English translation of Lu Xun's Nahan (2000), which claims that "these English translations are not only significant for introducing China to the outside world, but [are] also useful reading materials for domestic English learners and translators." Hung (2002: 331) notes that since 1980 a substantial number of "self-translations" of Chinese literature have been specially made for Chinese learners of English. This hitherto neglected topic is worthy of investigation as relevant research will offer insights into the following questions: Why are inverse translations commonly used for domestic consumption? What are the domestic users' attitudes toward inverse translations? How do they compare these translations with those by native TL translators? What role do inverse translations play in foreign language learning and translator training in China? What impact have they produced on Chinese students?

\subsubsection{Team Translation}

Lefevere (1998: 22) notes that "the Chinese tradition emphasises what we would now call teamwork, while the Western tradition has often frowned upon that very concept." Now it seems that this tradition is still prized in China. As shown above, most contemporary Chinese authors, whatever position they hold on inverse translation, tend to accept team translation as the best arrangement for translating out of Chinese. Why, then, does the Chinese tradition of teamwork continue well into today? What economic, socio-cultural, professional, linguistic reasons are involved? How do we compare the productions by team translators with those by individual translators? Which mode of collaboration - a native Chinese translator working with a TL stylist or translator, a native TL translator with a Chinese reviser or translator, or any other possible arrangement - can yield better results? Research questions like these have almost been left untouched to date, and they must be investigated via substantial corpus-based and empirical studies.

\section{Conclusion}

Translation practices in China feature the traditional Chinese-style team translation and "outward" translation as well as the present-day inverse non-literary translation. Chinese-style team translation, where foreign missionaries rendered religious texts or Western sci-tech works into Chinese with the aid of their Chinese collaborators, prevailed between the $2^{\text {nd }}$ and $19^{\text {th }}$ centuries. China's traditional dependence on foreign translators was caused by the lack of native translators, which in turn resulted from the traditional sense of cultural superiority that hindered the Chinese from learning foreign languages. The first wave of "outward" translations with a political agenda came in the 1950s-1960s. Translation of this nature continued from the 1970s through the mid-1990s when a new surge emerged, which appears to be gaining momentum today. Inverse non-literary translation began to be widely practiced since 
the late 1970s and is now the norm. The "outward" translation projects are mostly government-sponsored, as were the Chinese-style team translation endeavors. Both are essentially inverse translation and are intended for cultural export.

Although China has a long history of inverse translation, the issue of directionality was largely neglected before the early 1980s. At the turn of the $20^{\text {th }}$ century "inward" literary translation became the norm and the mother tongue principle came to be established. It was not challenged despite the first wave of "outward" translations in the 1950s-1960s. Since the early 1980s there has been much thinking about directionality, particularly about the suitability of native translators for handling inverse translation. But such is arguably not research in the true sense of the word, and the current use of improper terminology (e.g., yiru [译入] and yichu [译出]) often turns directionality into a highly charged issue, contributing little to serious research.

The lack of research on directionality reveals the fact that Chinese translation studies is still in its infancy, with tremendous efforts expended in "borrowing and copying Western translation theories" (Liu 2008: 188). However, since Western theories generally disregard the specificity of the Chinese language, they often do not apply well to translation between Chinese and Western languages. Moreover, as Harman (2006: 15) notes, "Western theorists have ignored Chinese as a language in translation, with very few exceptions." This means that the burden of addressing such deficiencies in research should be put on the shoulders of Chinese translation scholars. In an age of globalization, the struggle for survival of a less-translated language and culture is a common concern for many countries, including China. Now that English is the most important language in the world today, and readers and publishers in Anglophone countries are generally "resistant to literature in translation" (Wimmer 2001), China has no choice but to continue to rely on inverse translation if she wants to ensure that her voice is heard in the wider world. This adds even more significance and urgency to greater research efforts in the field.

With a long history of inverse translation behind her, China has rich research resources that are still to be explored. Chinese translation scholars must not be content with borrowing the theoretical results and empirical findings of their Western counterparts. What should be borrowed instead are the multiple approaches adopted, the various research methods used, and the breadth of research questions covered. Focusing on the specificity of the Chinese language and Chinese practice of inverse translation, Chinese translation scholars should be able to publish quality research that will not only inform practicing translators/interpreters and improve translator/ interpreter training, but will also contribute to international scholarship on directionality in particular and translation studies in general.

\section{NOTES}

1. There is no consensus about the terminology used to refer to directionality. Terms used to denote translation out of the native language include "inverse translation," " $A \rightarrow B$ translation," "retour interpreting," "service translation," "L1 $\rightarrow$ L2 translation," etc. "Inverse" and "retour" have been rejected for their negative connotations (Kelly, Martin et al. 2003: 35-40). This article generally refers to the procedure as inverse translation, although these terms are used interchangeably.

2. Interpreting out of Chinese is also very common in China. This article is mainly concerned with written translation.

3. In Shuttleworth and Cowie (2005), "directionality," "direct," "inverse" and "service" translation are rendered as fanyi fangxiang (翻译方向), zhijie fanyi (直接翻译), nixiang fanyi (逆向翻译) and 
fuwu xing fanyi (服务型翻译) respectively. But these terms are still very strange to the Chinese. And they can lead to misinterpretation: nixiang fanyi (逆向翻译) will render one at a loss as to what direction of translation nixiang means and what shunxiang ([顺向]; the opposite of nixiang [逆向］ in Chinese) refers to; fuwu xing fanyi (服务型翻译) might be thought of as translations done only for money's sake.

4. The "non-Chinese translators" for the three periods are: the Buddhist monks from the Western Region (Central Asia and today's Xinjiang in China) and India; the Jesuits; and Western missionaries.

5. One notable exception is Xuan Zang (602-664), the Chinese monk known for his pilgrimage to India (629-645). Having theological expertise and an excellent command of Sanskrit, Xuan Zang was in charge of the government-sponsored "translation forums" (yichang 译场) for twenty years. Therefore, the 1,300-odd volumes of translated sutras he is credited with are direct translations.

6. The general situation did not improve a lot until the College of Languages (Tongwen guan 同文 馆), China's first diplomat/translator training institution, was set up in 1862. However, China was still in need of foreign translators. For instance, the foreign teachers invariably took the leading role in the College's translation endeavors, with Chinese students serving as assistants (Xiong 1994: 317-320).

7. The most famous and prolific Chinese co-translators are Xu Guangqi (1562-1633) and Li Zhizao (1565-1630), both high-ranking government officials who did not know any foreign language.

8. Chinese scholars tend to overestimate the contributions of the Chinese collaborators by shunning their linguistic disadvantage. Ma (2006: 302-344), for example, omit the fact that the Chinese collaborators of the Jesuits had virtually no foreign language. All translations from the Chinese sources are made by the author of this article.

9. In 1935-1936 over 100 literary classics from a dozen of countries were made available to Chinese readers under a grand scheme called "World Library."

10. Another state-run institution is the Central Compilation and Translation Bureau (set up in 1953), which is mainly responsible for translating the Party and state documents and the writings of the Chinese leaders.

11. There are of course a few exceptions. American-born Sidney Shapiro, for example, translated the Chinese classic Shuihu Zhuan (Outlaws of the Marsh) as well as Ba Jin and Mao Dun. But Shapiro is a rare "reliable" case because he is one of very few naturalized citizens of the PRC.

12. Anonymous (12 January 2007): Bilingual Library of Chinese Classics Unveiled. Visited on 13 October 2009, <http://www.china.org.cn/2007-01/12/content_1195889.htm>.

13. Anonymous (12 January 2007): Brief Introduction of the Library of Chinese Classics. Visited on 2 April 2010, <http://www.china.org.cn/english/MATERIAL/195718.htm>.

14. Suggesting that English translations of classical Chinese poems by Chinese translators are often "awkward" and "move towards a kind of Sino-English," Graham $(1965: 24,37)$ claims that "we can hardly leave translation to the Chinese, since there are few exceptions to the rule that translation is best done into, not out of, one's own language."

15. Yang cites D. T. Roy's English translation of the classical Chinese novel Jin Ping Mei (Plum in the Golden Vase, 1993). According to Yang, Roy's putting one-sided stress on the raw elements in the original while neglecting its overall literary value has led to the distorted view that China was the "fountainhead of eroticism" and that a Chinese "tradition of permissiveness" was laid bare.

16. As of November 20, 2009. The journal database is mainly in Chinese while the latter two contain a large number of English theses.

17. For studies on directionality based on a simultaneous interpreting corpus, see Monti, Bendazzoli et al. (2005).

\section{REFERENCES}

BeEby, Allison (1996): Teaching Translation from Spanish to English. Ottawa: University of Ottawa Press.

BeEby, Allison (1998): Direction of translation (directionality). In: Mona BAKer, ed. Routledge Encyclopedia of Translation Studies. London/New York: Routledge, 63-67.

Beeby, Allison (2009): Directionality. In: Mona Baker and Gabriela SAldanha, eds. Routledge Encyclopedia of Translation Studies. London/New York: Routledge, 84-88. 
BIAN, Zhilin, YE, Shuifu, YUAN, Kejia, et al. (1959/1984): 艺术性翻译问题和诗歌翻译问题 [On literary translation and poetry translation]. In: Xinzhang Luo, ed., 翻译论集 [Collected papers on translation]. Beijing: Shangwu yinshuguan, 654-666.

Chan, Clara H. Y. (2007): Review of: Pokorn, Nike K. (2005): Challenging the Traditional Axioms: Translation Into a Non-mother Tongue. Babel. 53(3):284-288.

Chan, Leo Tak-hung (2003): Translation, transmission, and travel: Culturalist theorizing on "outward" translations of classical Chinese literature. In: Leo Tak-hung CHAN, ed. One Into Many: Translation and the Dissemination of Classical Chinese Literature. Amsterdam/New York: Rodopi, 321-346.

Chan, Leo Tak-hung (2004): Twentieth-century Chinese Translation Theory: Modes, Issues and Debates. Amsterdam/Philadelphia: John Benjamins.

Chang, Chia-chien and Schallert, Diane L. (2007): The impact of directionality on Chinese/ English simultaneous interpreting. Interpreting. 9(2):137-176.

Cheng, Zhenqiu (1980): 翻译问题探索 [Explorations into Translation Issues]. Beijing: Shangwu yinshuguan.

Cheng, Zhenqiu (1992): 汉英翻译问题 [Some problems in Chinese-English translation]. In: 中译英技巧文集 [Papers on Chinese-English translation techniques]. Beijing: Zhongguo duiwai fanyi chuban gongsi, 37-45.

CuI, Yonglu (2007): 试论中国经典文献外译的几个原则性问题 [On principles of translating Chinese classics]. Foreign Languages and their Teaching. 10:43-46.

DAI, Yannian and Chen, Rinong, eds. (1999): 中国外文局五十年大事记 [A chronology of China Foreign Languages Publishing and Distribution Administration (1949-1999)]. Beijing: New Star Press.

Davin, Delia (25 November 2009): Yang Xianyi. The Independent.

FAN, Cunzhong (1978/1984): 漫谈翻译 [On translation]. In: Xinzhang LUO, ed. 翻译论集 [Collected papers on translation]. Beijing: Shangwu yinshuguan, 778-792.

FENG, Zikai (1959/1984): 漫谈翻译 [On translation]. In: Xinzhang LUO, ed. 翻译论集 [Collected papers on translation]. Beijing: Shangwu yinshuguan, 645-646.

FERNÁNDEZ, Emilia Iglesias (2005): Bidirectionality in interpreter training in Spanish universities: An empirical study. In: Rita Godijns and Michaël Hinderdael, eds. Directionality in Interpreting: The 'Retour' or the Native? Special issue of Communication \& Cognition. $38(1 / 2), 101-125$.

GILE, Daniel (2005): Directionality in conference interpreting: A cognitive view. In: Rita GodIJNS and Michaël Hinderdael, eds. Directionality in Interpreting: The 'Retour' or the Native? Special issue of Communication \& Cognition. 38(1/2), 9-26.

GILE, Daniel (2009): Conference interpreting, historical and cognitive perspectives. In: Mona BAKer and Gabriela Saldanha, eds. Routledge Encyclopedia of Translation Studies. London/New York: Routledge, 51-56.

Godijns, Rita and Hinderdael, Michaël, eds. (2005): Directionality in Interpreting: The 'Retour' or the Native? Special issue of Communication \& Cognition. 38(1/2).

Graham, Angus Charles (1965): The translation of Chinese poetry. In: Poems of the late T'ang. (Translated by Angus Charles Graham) Harmondsworth: Penguin Books, 13-37.

Grosman, Meta, Kadric, Mira, Kovacic, Irena, et al. eds. (2000): Translation Into Non-mother Tongues in Professional Practice and Training. Tübingen: Stauffenburg.

Guo, Moruo (1923/1984): 理想的翻译之我见 [My view on ideal translation]. In: Xinzhang Luo, ed. 翻译论集 [Collected papers on translation]. Beijing: Shangwu yinshuguan, 331-333.

Harman, Nicky (2006): Foreign culture, foreign style. Perspectives. 14(1):13-31.

Hild, Adelina (2006): Review of: Godijns, Rita and Hinderdael, Michaël, eds. (2005): Directionality in Interpreting: The 'Retour' or the Native? Interpreting. 8(2):223-229.

Hu, Dexiang (2005): 文化研究语境下的中译英 [Chinese-English translation from the perspective of cultural studies]. Journal of Xiaogan University. 25(1):78-81.

Hu, Dexiang (2006): 对译入译出的文化思考 [Reflections on the cultural factors of translating into and from Chinese]. Journal of Hainan University. 24(3):355-359. 
Hu, Zhihui (29 January 2003): 谁来向国外译介中国作品 [Who should introduce Chinese writings to the outside world?]. China Reading Weekly.

Hung, Eva (1991): Blunder or service? The translation of contemporary Chinese fiction into English. Translation Review. 36/37:39-45.

Hung, Eva (1999): The role of the foreign translator in the Chinese translation tradition, 2nd to 19th century. Target. 11(2):223-243.

Hung, Eva (2000): A mono-cultural approach to translating classical Chinese poetry. In: Ngailai Cheng, ed. Translating Literary Texts: Theory and Practice. Hong Kong: Department of Chinese, The University of Hong Kong, 29-71.

Hung, Eva (2002): Translation and English in twentieth-century China. World Englishes. 21(2):325-335.

Hung, Eva and Pollard, David (1998): Chinese tradition. In: Mona Baker, ed. Routledge Encyclopedia of Translation Studies. London/New York: Routledge, 365-376.

JenneR, William J. F. (1990): Insuperable barriers? Some thoughts on the reception of Chinese writing in English translation. In: Howard GoldblatT, ed. Worlds apart: Recent Chinese writing and its Audiences. Armonk: M. E. Sharpe, 177-197.

Kelly, Dorothy, Martin, Anne, Nobs, Marie-Louise, et al., eds. (2003): La direccionalidad en traducción e interpretación: Perspectivas teóricas, profesionales y didácticas. Granada: Atrio.

LAO, Long (1996): 丢掉幻想 联系实践 [My view on translatology]. Chinese Translators Journal. 17(2):38-41.

LeE, Leo Ou-fan (1985): Contemporary Chinese literature in translation: A review article. The Journal of Asian Studies. 44(3):561-567.

Lefevere, André (1998): Chinese and Western thinking on translation. In: Susan BAssnetT and André Lefevere, eds. Constructing Cultures: Essays on Literary Translation. Clevedon: Multilingual Matters, 12-24.

LiANG, Qichao (1902/1989): 论小说与群治之关系 [On the relationship between fiction and social order]. In: Pingyuan CHEN and Xiaohong XIA, eds. 二十世纪中国小说理论资料 [Theoretic materials on Chinese fiction in the 20th century]. Beijing: Peking University Press, 33-37.

LIAO, Qiyi (2009): 东方翻译: 跨越东西方文化的桥梁 [East journal of translation: A bridge across Eastern and Western cultures]. East Journal of Translation. 1(1):16.

LiN, Yutang (1932/1984): 论翻译 [On translation]. In: Xinzhang Luo, ed. 翻译论集 [Collected papers on translation]. Beijing: Shangwu yinshuguan, 417-432.

LIU, Ching-chih (2008): 翻译: 学术、专业、半专业 [Translation as academic, professional or semi-professional pursuit]. Compilation and Translation Review. 1(1):183-192.

Lu, Xun (2000): Call to arms. (Translated by Xianyi YANG and Gladys YANG). Beijing: Foreign Languages Press.

Luo, Xinzhang, ed. (1984): 翻译论集 [Collected papers on translation]. Beijing: Shangwu yinshuguan [The Commercial Press].

MA, Zuyi and REN, Rongzhen (1997): 汉籍外译史 [History of World's Translations of Chinese Writings]. Wuhan: Hubei jiaoyu chubanshe.

MA, Zuyi (2006): 中国翻译通史 [A history of translation in China]. Wuhan: Hubei jiaoyu chubanshe.

Martin, Anne (2005): Interpreting from A to B: A Spanish case study. In: Rita Godijns and Michaël Hinderdael, eds. Directionality in Interpreting: The 'Retour' or the Native? Special issue of Communication \& Cognition. 38(1/2), 83-99.

McMorran, Ian (2000): Chinese: Literary translation into English. In: Olive Classe, ed. Encyclopedia of Literary Translation into English. London/Chicago: Fitzroy Dearborn, 278281.

Monti, Christina, Bendazzoli, Claudio, Sandrelli, Annalisa, et al. (2005): Studying directionality in simultaneous interpreting through an electronic corpus: EPIC (European Parliament Interpreting Corpus). Meta. 50(4). CD-ROM.

PAN, Wenguo (2004): 译入与译出:谈中国译者从事汉籍英译的意义 [Translating into/out of one's mother tongue]. Chinese translators journal. 25(2):40-43. 
Pavlović, Nataša (2007): Directionality in translation and interpreting practice: Report on a questionnaire survey in Croatia. In: Anthony Pym and Alexander Perekrestenko, eds. Translation research projects 1. Tarragona: Universitat Rovira i Virgili, 79-95.

Pokorn, Nike K. (2005): Challenging the Traditional Axioms: Translation Into a Non-mother Tongue. Amsterdam/Philadelphia: John Benjamins.

Pym, Anthony (1998): Method in Translation History. Manchester: St. Jerome.

RAMZY, Austin (20 October 2009): China's troubled coming-out at book fair. Visited on 20 March 2010, <http://www.time.com/time/world/article/0,8599,1931146,00.html>.

SETton, Robin (2009): Interpreting China, Interpreting Chinese. Interpreting. 11(2):109-117.

Shuttleworth, Mark and Cowie, Moira (1997): Dictionary of Translation Studies. Manchester: St. Jerome.

Shuttleworth, Mark and Cowie, Moira (2005): 翻译研究词典 [Dictionary of Translation Studies]. (Translated by Zaixi TAN, et al.). Beijing: Waiyu jiaoxue yu yanjiu chubanshe.

Thelen, Marcel (2005): Translating into English as a non-native language: The Dutch connection. In: Gunilla Anderman and Margaret Rogers, eds. In and Out of English: For Better, for Worse? Buffalo: Multilingual Matters, 242-255.

WANG, Binhua and Mu, Lei (2009): Interpreter training and research in mainland China: Recent developments. Interpreting. 11(2):267-283.

WANG, Ning (2000): 比较文学与当代文化批评 [Comparative Literature and Contemporary Cultural Criticism]. Beijing: Renmin wenxue chubanshe.

WANG, Yan (9 May 2008): 谢天振: 如何向世界告知中华文化 [How to introduce Chinese culture to the world: An interview with Xie Tianzhen]. Liaoning Daily.

Wimmer, Natasha (21 May 2001): The U.S. translation blues. Publishers Weekly.

Wu, Jingrong (1986): 中国古典诗歌的翻译 [On English translation of classical Chinese poetry]. Diplomatic Review. 2:5-17.

XIE, Tianzhen (2007): 译介学导论 [Introduction to Medio-Translatology]. Beijing: Peking University Press.

XIONG, Yuezhi (1994): 西学东渐与晚清社会 [The Dissemination of Western Learning and the Late Qing Society]. Shanghai: Shanghai renmin chubanshe.

Xu, Jianzhong (2005): Training translators in China. Meta. 50(1):231-249.

YAN, Fu (1898/1984): 天演论译例言 [Preface to Tianyan Lun]. In: Xinzhang Luo, ed. 翻译论集 [Collected papers on translation]. Beijing: Shangwu yinshuguan, 136-138.

YANG, Muzhi (1999): Preface to the Library of Chinese classics. Visited on 25 October 2009, $<$ http://www.china.org.cn/english/MATERIAL/195723.htm>.

YANG, Zhengquan (1999): 序 [Introduction]. In: Yannian DAI and Rinong Chen, eds. 中国外文 局五十年大事记 [A chronology of China Foreign Languages Publishing and Distribution Administration (1949-1999)]. Beijing: New Star Press, I-VI.

Yu, Shiyi (2007): Translation as participation: A reflection on the recent surge of English translation of Chinese classics in China. Neohelicon. 34(2):91-99.

ZHu, Chunshen (2004): Translation studies in China or Chinese-related translation studies: Defining Chinese translation studies. Babel. 50(4):332-345. 